\title{
Treatment-Seeking for Symptoms of Reproductive Tract Infections Among Young Women in India
}

\section{By Shagun Sabarwal and K.G.Santhya}

Shagun Sabarwal is a Fred H. Bixby fellow, and K. G. Santhya is an associate II, both with the Population Council, New Delhi.

\begin{abstract}
CONTEXT: Small proportions of Indian women report seeking treatment for symptoms suggestive of reproductive tract infections (RTIs). Most studies on treatment-seeking have focused broadly on women of reproductive age, and little is known about the experiences of adolescent girls and young women, particularly the unmarried.
\end{abstract}

METHODS: Data from 2,742 married and 2,108 unmarried women aged 15-24 who reported at least one symptom of an RTI in the past three months were drawn from a subnationally representative survey of youth in India in 2006-2008. Multivariate logistic regression analysis was conducted to identify associations between respondents' characteristics and treatment-seeking from a formal medical provider. In addition, among those who had used such providers, associations between characteristics and use of private rather than public providers were identified.

RESULTS: About two-fifths of married and one-third of unmarried women had sought treatment from formal medical providers for their RTI symptoms. While married women's experience of intimate partner violence was negatively associated with seeking treatment from a formal provider (odds ratio, 0.8), their perceived access to sexual and reproductive health services and their awareness of STI symptoms were positively associated with such treatment (1.3-1.4). Both married and unmarried women were more likely to seek treatment from private than from public providers, and two indicators of women's autonomy were positively correlated with using private providers (1.6-2.8).

CONCLUSIONS: Limited treatment-seeking for RTI symptoms by young women underscores the need to address power imbalances within marriage and to encourage health care providers to develop appropriate strategies to reach younger, as well as unmarried, women.

International Perspectives on Sexual and Reproductive Health, 2012, 38(2):90-98, doi:10.1363/3809012
In India, research and programmatic attention to women's experience of reproductive tract infections (RTIs), including STIs, has increased considerably through the 1990s and 2000s. Several policies and programs-including the National Population Policy 2000, ${ }^{1}$ the National Health Policy 2002, ${ }^{2}$ the National Rural Health Mission $2005^{3}$ and the National AIDS Control Programme Phase III ${ }^{4}$ have stressed the need for expanding women's access to services for prevention, screening and management of RTIs. Moreover, several small- and large-scale studies have documented a high prevalence of RTIs among women and shown that significant proportions of symptomatic women do not seek treatment. ${ }^{5-20}$ Studies examining characteristics that are correlated with women's ability to seek treatment, however, are sparse, ${ }^{6}$ and even less research has focused on young women.

To address these gaps, this article uses data from a subnationally representative survey of young people in India to describe the prevalence of RTI symptoms among married and unmarried women and their treatment-seeking behavior. We assess associations between women's characteristics and seeking treatment from formal medical providers, as well as between characteristics and treatment from private-sector instead of public-sector providers.

\section{BACKGROUND}

The prevalence of self-reported RTI symptoms among Indian women has been found to be $11-18 \%$ in nationally representative studies ${ }^{7,8}$ and $40-57 \%$ in small-scale studies, ${ }^{9-11}$ while the prevalence of laboratory-diagnosed RTIs has ranged from $28 \%$ to $38 \%{ }^{11,12}$ Moreover, women aged 15-24 were as likely as those aged 25-39 to report symptoms of RTIs. ${ }^{8}$ According to studies that have explored women's patterns of seeking treatment for RTI symptoms, between one-third and two-thirds of symptomatic women did not seek treatment. ${ }^{9,11-20}$ In the few studies that specifically examined treatment-seeking among married adolescent girls and young women, these subgroups were less likely than others to have sought treatment for RTI symptoms. ${ }^{11,12,16,21,22}$

Although few studies have explored measures that are correlated with women's ability to seek treatment for symptoms of RTIs, ${ }^{6}$ a number of associated characteristics have been found. Women who were young, less educated or economically disadvantaged, or who belonged to socially excluded groups, were less likely than their counterparts to have sought treatment. ${ }^{9-11}$ In addition, women who adhered to unequal gender norms or who lacked autonomy in household decision making had a reduced like- 
lihood of having sought treatment. ${ }^{13,15}$ One study found that contact with a health care provider (i.e., a visit from an outreach worker or to a health facility in the past year) was associated with an increased likelihood of treatmentseeking, ${ }^{15}$ whereas distance to the nearest public-sector health facility was inconsistently correlated. ${ }^{9,11,12}$ Finally, other studies have found that women with RTI symptoms carry a substantial social burden of guilt and shame, and that the perceived association between RTI symptoms and sexual infidelity was correlated with a reduced likelihood of seeking timely and effective treatment. ${ }^{12,16,23,24}$

To date, the large majority of studies on treatmentseeking for symptoms of RTIs have focused on evermarried women of reproductive age, and only a few have looked specifically at married young women. ${ }^{12,16}$ Little research has focused on unmarried young women; indeed, after an extensive search, we found only one such study in India-a qualitative one. ${ }^{25}$ The present study contributes to the literature by using data from a large, subnational, population-based sample of married and unmarried young women in six states of India to examine the correlates of treatment-seeking patterns among young women.

\section{METHODS \\ Study Setting}

The Youth in India: Situation and Needs survey was conducted in 2006-2008 among representative samples of youth drawn from rural and urban areas of six states in India: Andhra Pradesh, Bihar, Jharkhand, Maharashtra, Rajasthan and Tamil Nadu. According to the 2001 Indian census, the youth in these states account for 39\% of the total youth population in the country. ${ }^{26}$ The distributions of the sampled youth by age, literacy, religion, caste and marital status were similar to those of the youth population nationally. These states were, however, selected to represent different geographic and sociocultural regions of the country, and lie at the extremes of the socioeconomic and cultural spectrums. Andhra Pradesh, Maharashtra and Tamil Nadu are among the more economically progressive states, each accounting for $7-13 \%$ of the national gross domestic product (GDP), while Bihar, Jharkhand and Rajasthan are among the less developed states, each accounting for 2-4\% of the GDP. ${ }^{27}$ Maharashtra and Tamil Nadu are among the most urbanized states, with more than two-fifths of their populations living in urban areas. In contrast, Bihar, Jharkhand and Rajasthan are characterized by large rural populations, with just one-tenth to onequarter of their populations living in urban areas. ${ }^{28}$ In addition, the prevalence of self-reported RTIs among women of reproductive age also varies across these states, with estimates ranging from $7 \%$ in Tamil Nadu to $21 \%$ in Bihar. ${ }^{7}$

\section{Survey}

The survey focused on married and unmarried women and unmarried men aged 15-24 and, because of the paucity of married males in this age-group, married men aged 15-29. Rural and urban areas were treated as independent sampling domains, and a systematic, multistage stratified sampling design was used to draw sample areas independently for each of these two domains. In each primary sampling unit, interviews were conducted with either males or females to avoid the risks of teasing, harassment, harm to women's reputations and even violence. Households from each unit were selected by systematic sampling. Within each selected household, no more than one respondent was interviewed from each marital category (i.e., a maximum of two respondents-one married and one unmarried). If a household had more than one respondent from a category, one was selected randomly, and no replacement was allowed.

The survey was conducted by trained researchers in 2006 in Jharkhand, Maharashtra and Tamil Nadu, and in 2007-2008 in Andhra Pradesh, Bihar and Rajasthan. A total of 50,848 respondents were interviewed (11,522 unmarried and 8,052 married men, and 17,362 unmarried and 13,912 married women). Response rates ranged from $84 \%$ to $90 \%$; the main reason for nonresponse was that the respondent was not at home. Only $1 \%$ or fewer respondents refused to participate. We attribute the low refusal rate to the strategies adopted to address ethical concerns, which also enabled the development of rapport and trust between study communities and interview teams. For example, youth themselves contributed to the development of the questionnaire; study teams apprised community leaders in each primary sampling unit and sought their support for its implementation; and study coordinators trained interviewers on how to ask sensitive questions in empathetic and nonjudgmental ways, and emphasized the importance of offering to refer those in need of information or services to appropriate nearby organizations. In addition, every effort was made to maintain privacy during the interview, including permitting interviewers to skip to relatively nonsensitive sections in case the interview was observed by parents or other family members, and assigning an additional interviewer to each team to conduct an informal discussion with family members if they attempted to participate in or overhear the interview.

The development of the questionnaire was informed by other survey instruments and insights obtained in a preliminary qualitative phase. The questionnaire was finalized after extensive pretesting. The survey included questions about respondents' background characteristics, autonomy, awareness of sexual and reproductive health matters, spousal and parental communication, experience of physical or sexual violence, experience of symptoms of RTIs and treatment-seeking behavior.

\section{Dependent Variables}

To assess the prevalence of symptoms suggestive of RTIs, respondents were asked whether they had experienced genital ulcers, genital itching, swelling in the groin, abnormal genital discharge or a burning sensation during urination in the three months preceding the interview. All who had experienced at least one of these were asked whether 


\begin{tabular}{|c|c|c|}
\hline Characteristic & $\begin{array}{l}\text { Married } \\
(\mathrm{N}=2,742)\end{array}$ & $\begin{array}{l}\text { Unmarried } \\
(\mathrm{N}=2,108)\end{array}$ \\
\hline \multicolumn{3}{|l|}{ Social and demographic } \\
\hline Age (mean) & 20.9 & $17.8^{* * *}$ \\
\hline Yrs. of schooling completed (mean) & 4.7 & $8.4^{* * *}$ \\
\hline Currently working & 44.5 & $40.6^{*}$ \\
\hline Household wealth index (mean) & 14.5 & $17.7^{* * *}$ \\
\hline Urban residence & 9.9 & $14.6^{* * *}$ \\
\hline \multicolumn{3}{|l|}{ Religion } \\
\hline Hindu & 84.9 & $81.3^{* * *}$ \\
\hline Muslim & 10.8 & 10.5 \\
\hline Other & 4.4 & 8.2 \\
\hline \multicolumn{3}{|l|}{ Castet } \\
\hline Scheduled tribe & 5.9 & $6.7^{*}$ \\
\hline Scheduled caste & 21.1 & 24.7 \\
\hline Other backward caste & 54.9 & 49.3 \\
\hline General caste & 17.5 & 18.6 \\
\hline \multicolumn{3}{|l|}{ Region } \\
\hline Northern & 54.8 & $27.4^{* * *}$ \\
\hline Western & 19.1 & 26.8 \\
\hline Southern & 26.1 & 45.8 \\
\hline \multicolumn{3}{|l|}{ Agency } \\
\hline Makes independent decisions on personal matters & 23.3 & $27.2^{* *}$ \\
\hline Free to visit health facility unescorted $\neq$ & 18.8 & 16.7 \\
\hline \multicolumn{3}{|l|}{ Has/manages bank/post office account } \\
\hline Has none & 90.3 & $84.6^{* * *}$ \\
\hline Has account but does not manage & 4.1 & 7.6 \\
\hline Manages account & 5.3 & 7.8 \\
\hline \multicolumn{3}{|l|}{ Awareness of symptoms } \\
\hline Aware of at least one STI symptom & 18.0 & $10.1^{* * *}$ \\
\hline \multicolumn{3}{|l|}{ Perceived access } \\
\hline Could approach a provider for contraceptives§ & 53.2 & $38.4^{* * *}$ \\
\hline \multicolumn{3}{|l|}{ Marital relationship } \\
\hline Communicated with husband about reproductive matters & 57.6 & na \\
\hline Experienced physical/sexual violence by husband in last 12 mos. & 44.2 & na \\
\hline \multicolumn{3}{|l|}{ Family environment } \\
\hline Would confide in parent about menstrual problems & na & 85.7 \\
\hline Ever beaten by a parent since age $12+\dagger$ & na & 32.7 \\
\hline
\end{tabular}

${ }^{*} p \leq .05 .{ }^{* *} p \leq .01 .{ }^{* * *} p \leq .001 .+$ Missing in 21 cases. Scheduled tribes and scheduled castes are recognized by the government of India as being socially disadvantaged. \#Missing in two cases. \$Missing in 11 cases. t+Missing in 33 cases. Notes: All figures are percentages unless indicated otherwise. Percentages may not add to 100.0 because of missing cases. na=not applicable.

they had sought treatment for the complaint, and if so, where they had gone the last time. Using these responses, we classified symptomatic women into four groups: no treatment, treatment from a public-sector doctor or facility, treatment from a private-sector doctor or facility, and treatment from a traditional health care provider or reliance on

\begin{tabular}{|l|l|}
$\begin{array}{l}\text { TABLE 2. Percentage distribution of women who had expe- } \\
\text { rienced at least one symptom of a reproductive tract infec- } \\
\text { tion in the past three months, by treatment-seeking behav- } \\
\text { ior, according to marital status }\end{array}$ \\
\begin{tabular}{lcc} 
Treatment & Married & Unmarried \\
\hline None & 57.4 & 66.4 \\
Public-sector provider & 10.6 & 10.1 \\
Private-sector provider & 28.3 & 19.9 \\
Traditional provider/home remedy & 3.4 & 3.5 \\
& & \\
Total & 100.0 & 100.0
\end{tabular}
\end{tabular}

home remedies. Moreover, we defined those who sought treatment from a doctor or facility as having obtained treatment from a formal provider.

\section{Independent Variables}

We collected information on respondents' age, years of schooling completed, work status ("currently working" was defined as having worked in the last 12 months), place of residence (rural or urban), religion (Hindu, Muslim, other), caste* (scheduled tribe, scheduled caste, other backward caste, general caste) and household economic status. The last variable was measured using a wealth index, composed of household ownership of 16 durable goods and assets, as well as use of various amenities (toilet facilities, access to electricity, sources of drinking water and cooking fuel); possible scores ranged from 0 to $54 .{ }^{27}$ Finally, because a regional pattern was observed for many measuresfor example, youth in the three northern states tended to be more disadvantaged than those in the other states ${ }^{29}$-we included residence by region, as follows: northern (Bihar, Jharkhand and Rajasthan), western (Maharashtra) and southern (Andhra Pradesh and Tamil Nadu).

We considered three indicators of women's agency. Decision-making autonomy assessed whether the respondent made independent decisions in her choice of friends, spending her own money and buying her clothes; this measure was scored dichotomously, as either "yes" to all items or "no" to any. Freedom of movement indicated whether she was permitted to visit a health facility unescorted. The third measure assessed whether the respondent had an account in a bank or post office and, if so, whether she managed it on her own. As a proxy for awareness of sexual and reproductive health matters, respondents were asked whether they were aware of at least one symptom of STIs. To gauge their access to sexual and reproductive health services, we asked whether they thought they could approach a health care provider for contraceptives.

For married women, we considered two relationship variables. To assess spousal communication about reproductive matters, we asked respondents if they had ever talked with their husband about whether and when to have children, the number of children to have and contraceptive use; this was scored dichotomously, as either "yes" to all items or "no" to any. Marital violence was assessed by asking whether respondents had experienced physical or sexual violence at the hands of their husband in the preceding 12 months.

For unmarried women, we included two variables regarding their family environment while growing up. Parental connectedness was assessed by asking respondents whether they would confide in either of their parents if they faced a menstrual problem; respondents aged 20 or

*Scheduled tribes and scheduled castes are recognized by the government of India as being socially disadvantaged.

tInterviewers asked respondents whether they had heard about any infections other than HIV that people could get from sexual contact, and if so, what were some of the symptoms. 
older answered this question for when they were about 15-18 years old. Respondents were also asked whether they had ever been beaten by a parent since age 12 .

\section{Analysis}

We first present descriptive data for 2,742 married and 2,108 unmarried women regarding the prevalence of symptoms of RTIs, the characteristics of symptomatic women and the pattern of seeking treatment for these symptoms. We examined differences in these variables by marital status using t tests or chi-square tests. Multivariate logistic regression analysis was used to examine correlates of treatment-seeking from formal providers among symptomatic respondents (2,540 married and 1,973 unmarried women). Among those who had sought treatment from formal providers, regression analysis was conducted to assess correlates of treatment-seeking from private-sector as opposed to public-sector providers (1,088 married and 575 unmarried women). Only 3-4\% of respondents had sought treatment from traditional health care providers or had relied on home remedies, and these women were excluded from the multivariate analysis. Appropriate weights were applied and Stata version 10 was used for all analyses.

\section{RESULTS}

\section{Prevalence of RTI Symptoms}

Seventeen percent of the young women in the full sample reported having had symptoms of RTIs in the three months preceding their interviews. Married women were more likely than unmarried women to report having had symptoms (20\% vs. $13 \%$ ), and prevalence ranged from 11-17\% in Andhra Pradesh, Maharashtra, Rajasthan and Jharkhand to 21-22\% in Bihar and Tamil Nadu.

\section{Descriptive Characteristics}

Although the full sample of young women included in the larger study was nationally representative, ${ }^{29}$ the characteristics of our subsample of women, who had reported a recent RTI symptom, differed somewhat from those of the larger sample. Among respondents who had experienced at least one RTI symptom in the past three months, married women were typically older than unmarried women (21 vs. 18), had fewer years of schooling ( 5 vs. 8), were more likely to be currently working ( $45 \%$ vs. $41 \%$ ), were from more economically disadvantaged families (mean score of 15 vs. 18 on the household wealth index) and were less likely to live in an urban area (10\% vs. $15 \%-$ Table 1). Married and unmarried respondents were significantly different regarding religious background and caste membership, as well as in their geographic distributions: A higher proportion of married than of unmarried women resided in the northern states (55\% vs. $27 \%$ ), and lower proportions resided in the western (19\% vs. $27 \%$ ) and southern states ( $26 \%$ vs. $46 \%$ ).

About one in five of each group said they were free to visit a health facility without an escort. Married women were less likely than unmarried women to make indepen-
TABLE 3. Odds ratios (and 95\% confidence intervals) from multivariate logistic regression analysis to identify associations between selected characteristics and seeking treatment from a formal provider, by marital status

Characteristic

$\begin{array}{ll}\text { Married } & \text { Unmarried } \\ (\mathrm{N}=2,540) & (\mathrm{N}=1,973)\end{array}$

Social and demographic

Age

Yrs. of schooling completed

Currently working

No (ref)

Yes

Household wealth index

Residence

Rural (ref)

Urban

Religion

Hindu (ref)

Muslim

Other

Castet

Scheduled tribe (ref)

Scheduled caste

Other backward caste

General caste

Region

Northern (ref)

Western

Southern

$\begin{array}{ll}1.02(0.97-1.07) & 1.12(1.06-1.18)^{* * *} \\ 1.04(1.00-1.07)^{*} & 1.00(0.96-1.04) \\ 1.00 & 1.00 \\ 0.96(0.77-1.19) & 1.07(0.82-1.40) \\ 1.02(1.00-1.03)^{*} & 1.00(0.98-1.01) \\ 1.00 & 1.00 \\ 1.16(0.91-1.47) & 1.31(0.98-1.74) \\ 1.00 & 1.00 \\ 1.19(0.85-1.68) & 1.29(0.81-2.05) \\ 1.38(0.85-2.26) & 0.63(0.40-0.99)^{*} \\ & \\ 1.00 & 1.00 \\ 1.32(0.77-2.29) & 1.49(0.83-2.68) \\ 1.27(0.74-2.18) & 1.12(0.64-1.97) \\ 1.43(0.79-2.60) & 1.35(0.72-2.54) \\ 1.00 & 1.00 \\ 1.84(1.32-2.57)^{* * *} & 2.26(1.50-3.43)^{* * *} \\ 3.20(2.40-4.25)^{* * *} & 2.96(2.16-4.04)^{* * *}\end{array}$

Agency

Makes independent decisions on personal matters No (ref)

Yes

1.00

Free to visit health facility unescorted

No (ref)

Yes

$1.08(0.86-1.35) \quad 0.95(0.71-1.28)$

$1.00 \quad 1.00$

$1.02(0.79-1.31) \quad 1.19(0.83-1.71)$

Has/manages bank/ post office account

Has none (ref)

Has account but does not manage

Manages account

1.00

1.00

$1.11(0.68-1.82) \quad 1.04(0.66-1.64)$

$1.03(0.67-1.58) \quad 1.38(0.91-2.07)$

Awareness of symptoms

Aware of at least one STI symptom

No (ref)

Yes

$1.00 \quad 1.00$

$1.35(1.04-1.77)^{*} \quad 1.15(0.77-1.73)$

Perceived access

Could approach a provider for contraceptives No (ref)

Yes

$1.00 \quad 1.00$

$1.27(1.01-1.60)^{*} \quad 1.00(0.79-1.27)$

Marital relationship

Communicated with husband

about reproductive matters

No (ref)

Yes

1.00

$1.13(0.90-1.42)$

Experienced physical/sexual violence

by husband in last $12 \mathrm{mos}$.

No (ref)

1.00

Yes

$0.77(0.63-0.96)^{*}$

Family environment

Would confide in parent about menstrual problems No (ref)

Yes

na $\quad 1.00$

Ever beaten by a parent since age 12

No (ref)

na

$1.33(0.95-1.85)$

Yes

na

1.00

${ }^{*} \mathrm{p} \leq .05 .{ }^{* * *} \mathrm{p} \leq .001 . \dagger$ Scheduled tribes and scheduled castes are recognized by the government of India as being socially disadvantaged. Notes: Respondents who were excluded from this analysis were similar to those included regarding most social and demographic characteristics. ref=reference group. na=not applicable. 


\begin{tabular}{|c|c|c|}
\hline Characteristic & $\begin{array}{l}\text { Married } \\
(\mathrm{N}=1,088)\end{array}$ & $\begin{array}{l}\text { Unmarried } \\
(\mathrm{N}=575)\end{array}$ \\
\hline \multicolumn{3}{|l|}{ Social and demographic } \\
\hline Age & $0.92(0.85-0.99)^{*}$ & $1.04(0.95-1.14)$ \\
\hline Yrs. of schooling completed & $1.00(0.95-1.05)$ & $0.92(0.85-1.00)^{*}$ \\
\hline \multicolumn{3}{|l|}{ Currently working } \\
\hline No (ref) & 1.00 & 1.00 \\
\hline Yes & $0.83(0.55-1.25)$ & $0.71(0.43-1.16)$ \\
\hline Household wealth index & $1.02(0.99-1.04)$ & $1.06(1.02-1.09)^{* * *}$ \\
\hline \multicolumn{3}{|l|}{ Residence } \\
\hline Rural (ref) & 1.00 & 1.00 \\
\hline Urban & $1.14(0.76-1.72)$ & $1.57(0.91-2.71)$ \\
\hline \multicolumn{3}{|l|}{ Religion } \\
\hline Hindu (ref) & 1.00 & 1.00 \\
\hline Muslim & $1.29(0.70-2.36)$ & $0.90(0.41-1.97)$ \\
\hline Other & $1.58(0.66-3.80)$ & $0.86(0.33-2.24)$ \\
\hline \multicolumn{3}{|l|}{ Castet } \\
\hline Scheduled tribe (ref) & 1.00 & 1.00 \\
\hline Scheduled caste & $0.85(0.38-1.91)$ & $1.13(0.35-3.65)$ \\
\hline Other backward caste & $1.50(0.67-3.36)$ & $1.55(0.48-5.06)$ \\
\hline General caste & $1.18(0.49-2.85)$ & $5.16(1.30-20.49)^{*}$ \\
\hline \multicolumn{3}{|l|}{ Region } \\
\hline Northern (ref) & 1.00 & 1.00 \\
\hline Western & $1.40(0.77-2.53)$ & $1.27(0.55-2.94)$ \\
\hline Southern & $1.03(0.68-1.55)$ & $0.80(0.43-1.51)$ \\
\hline
\end{tabular}

Agency

Makes independent decisions on personal matters No (ref)

Yes

Free to visit health facility unescorted

No (ref)

Yes

Has/manages bank/post office account

Has none (ref)

Has account but does not manage

Manages account

$1.00 \quad 1.00$

$1.61(1.05-2.47)^{*} \quad 1.82(1.07-7.16)^{*}$

$1.00 \quad 1.00$

$1.07(0.70-1.62) \quad 0.63(0.36-1.09)$

$1.00 \quad 1.00$

$1.04(0.43-2.56) \quad 1.05(0.38-2.89)$

$1.97(0.96-4.02) \quad 2.77(1.07-7.16)^{*}$

\section{Awareness of symptoms}

Aware of at least one STI symptom

No (ref)

Yes

$1.00 \quad 1.00$

$0.84(0.55-1.26) \quad 0.96(0.44-2.08)$

\section{Perceived access}

Could approach a provider for contraceptives No (ref)

Yes

$\begin{array}{ll}1.00 & 1.00 \\ 1.10(0.79-1.52) & 1.86(1.19-2.91)^{* *}\end{array}$

\section{Marital relationship}

Communicated with husband

about reproductive matters

No (ref)

Yes

Experienced physical/sexual violence

by husband in last $12 \mathrm{mos}$.

No (ref)

Yes

$1.00 \quad$ na

$0.96(0.63-1.47) \quad$ na

$1.00 \quad$ na

$0.94(0.66-1.35) \quad$ na

Family environment

Would confide in parent about menstrual problems No (ref)

Yes

Ever beaten by a parent since age 12

No (ref)

Yes

$\begin{array}{ll}\text { na } & 1.00 \\ \text { na } & 1.44(0.78-2.63) \\ & \\ \text { na } & 1.00 \\ \text { na } & 1.17(0.73-1.86)\end{array}$

${ }^{*} \mathrm{p} \leq .05 .{ }^{* *} \mathrm{p} \leq .01 .{ }^{* * *} \mathrm{p} \leq .001 .+S c h e d u l e d$ tribes and scheduled castes are recognized by the government of India as being socially disadvantaged. Notes: ref=reference group. na=not applicable. dent decisions on personal matters (23\% vs. $27 \%$ ) and to have a bank or post office account ( $9 \%$ vs. $15 \%$ ), but were more likely to be aware of at least one STI symptom (18\% vs. 10\%) and to believe they could approach a health care provider for contraceptives (53\% vs. 38\%).

Fifty-eight percent of married women reported that they had communicated with their spouses about reproductive matters, and 44\% said they had experienced physical or sexual violence at the hands of their husband in the last year. Among unmarried women, 86\% said they would confide in a parent about menstrual problems, and 33\% had been beaten by a parent since age 12 .

\section{Treatment-Seeking for RTI Symptoms}

Among respondents who had experienced symptoms of RTIs, $57 \%$ of married and $66 \%$ of unmarried women had not sought any treatment for their symptoms (Table 2 , page 92). Two-fifths of married women had sought treatment from formal medical providers ( $11 \%$ from the public sector and $28 \%$ from the private sector), as had one-third of unmarried women (10\% and 20\%, respectively). Only $3-4 \%$ of either group had relied on traditional health care providers or home remedies.

\section{Correlates of Using Formal Providers}

Separate multivariate analyses for married and unmarried women identified characteristics correlated with seeking treatment for RTI symptoms from formal medical providers (Table 3, page 93). Among married women, years of schooling and household wealth index were positively associated with treatment-seeking (odds ratios, 1.04 and 1.02 , respectively), while age was positively associated with treatment-seeking among unmarried women (1.1). Regional patterns in treatment-seeking were observed: Young women-married or unmarried-who lived in the western state of Maharashtra or the southern states were more likely than their northern counterparts to have sought treatment from formal providers (1.8-3.2)

Notably, none of the measures of women's agency was associated with seeking treatment from formal providers among either subgroup. However, married respondents who were aware of at least one STI symptom had elevated odds of having sought treatment from a formal provider (odds ratio, 1.4), as did those who believed they could approach a provider for contraceptives (1.3).

Only one of the marital relationship measures was significant: Married women who had experienced physical or sexual violence by their husband in the last year had reduced odds of having sought treatment from a formal provider (odds ratio, 0.8).

\section{Correlates of Using Private Versus Public Providers}

In a multivariate analysis of respondents who had sought treatment for RTI symptoms from formal medical providers, among married women, only two characteristics were significant for use of private providers: Age was negatively associated with seeking treatment from private providers 
rather than public ones (odds ratio, 0.9), while the reverse was true for decision-making autonomy (1.6-Table 4). Among unmarried women, household wealth index, membership in a general caste, decision-making autonomy, control over one's bank or postal account, and perceived access to sexual and reproductive health services were positively associated with seeking treatment from a private provider instead of a public one (1.1-5.2), whereas years of schooling was inversely associated with using private providers (0.9).

\section{DISCUSSION}

Our findings show that treatment-seeking for symptoms of RTIs is limited among young women in India: Fewer than half of married respondents and a third of unmarried ones who had recently experienced symptoms had sought treatment. These rates are consistent with those found in previous research in India ${ }^{9,11,12}$ and underscore that, although the country's Reproductive and Child Health Programme has advocated special services for youth, including the unmarried, these services have failed to reach most young women. The majority of earlier studies focused solely on married young women, and hence little is known about treatment-seeking patterns among their unmarried counterparts. The low level of treatment-seeking among this study's unmarried youth corroborated findings from an earlier qualitative study. ${ }^{25}$ This level was lower than that among married women, which may indicate that reproductive health symptoms evoke greater embarrassment among unmarried women and their families than among their married counterparts.

Our study identified a number of correlates of seeking treatment from formal providers, and notably, different sets of characteristics were correlated with treatmentseeking among married and unmarried women. Indeed, for unmarried women, only the background characteristics of age and state of residence showed associations, and none of the variables measuring women's resources to adopt healthy practices-schooling, autonomy, awareness of sexual and reproductive matters, a supportive family environment and perceived access to reproductive health services-was significant. These findings are in line with those from previous studies in India and elsewhere, and may suggest that the stigma, shame and social isolation associated with RTIs are more acute for unmarried young women than for their married counterparts, and are likely to deter them from seeking treatment from formal providers in the public or private sector. ${ }^{25,30-32}$ Our results may also reflect the lack of focus on unmarried women in government programs aimed at improving youth's sexual and reproductive health, as documented by past research. ${ }^{33}$

A greater number of measures were correlated with married young women's treatment-seeking behaviors. For example, as observed in other studies, ${ }^{13}$ schooling was associated with seeking treatment from formal providers, likely because young women with more schooling had more information about protective actions and the re- sources to adopt them than did others. Similarly, as found in an earlier study, ${ }^{34}$ our results indicate that married young women who were aware of symptoms of STIs were more likely than others to have sought treatment from formal providers. Studies that have examined the influence of intimate partner violence on adverse reproductive health outcomes often hypothesize that the deterrent effect of violence on women's use of health services is a possible pathway to an elevated risk of adverse outcomes. ${ }^{35-38}$ Our findings provide considerable support for this hypothesis.

Other studies in India and elsewhere $9,12,16,39-41$ have found that accessibility was associated with seeking treatment for RTIs from formal providers. In our study, married young women who thought they could approach a provider for reproductive health services were more likely than others to have sought treatment from formal providers and facilities. Moreover, earlier studies have observed that limited decision-making authority, limited mobility and lack of control over resources may inhibit women's ability to seek care for gynecological problems in India., $9,12,16,40,42$ We found no associations between indicators of women's agency and treatment-seeking from formal medical providers; however, two agency measures were correlated with women's choice of a private rather than a public provider. The regional differences observed in women's treatmentseeking may reflect the increased awareness of sexual and reproductive health matters, as well as better access to formal providers and facilities in the southern states and the western state of Maharashtra than in the northern states.,8

Consistent with past research, ${ }^{11,12,43,44}$ this study found that regardless of their marital status, the majority of women who had sought care had consulted private providers, suggesting that a preference for these providers persists despite the numerous initiatives undertaken by the Indian government to improve access to sexual and reproductive health services in the public sector. Furthermore, among the unmarried women who had sought treatment from formal providers, those who were better off-belonging to richer households or general castes, displaying personal agency and reporting perceived access to services-were more likely to have sought treatment from private-sector providers. Since public-sector facilities are currently not geared to serve unmarried youth adequately, it appears that they largely attract the young women who do not have resources to seek services from private providers.

\section{Limitations}

These findings need to be interpreted in light of certain limitations. First, the cross-sectional nature of the study precludes the assessment of causality. Second, previous studies in India have reported that even when treatment is sought, women tend to follow a sequence of options, ranging from self-treatment or home remedies to visiting traditional healers, unqualified practitioners or qualified allopathic providers. ${ }^{39,41,45}$ Our study collected information about the treatment option that was last sought, thereby limiting our ability to shed light on the range of treatment 
options sought by young women and the characteristics correlated with these choices. A third limitation is that our sample comprised young women who had recognized an RTI symptom; many RTIs are asymptomatic and selfreports do not necessarily predict actual morbidity. Hence, our findings cannot be generalized to treatment-seeking for all RTIs. A fourth limitation is that respondents may not always have been able to discern whether the privatesector provider from whom they had sought treatment had been trained and was licensed to provide such treatment, and so these findings should be interpreted with caution. Finally, unmeasured variables-for example, indicators of cultural beliefs and health system services-may confound the associations found in our analysis.

\section{Conclusions}

Low levels of treatment-seeking among young women in India highlight the need to sensitize health care providers about the special needs, heterogeneity and vulnerability of unmarried and married women, and to encourage providers to develop appropriate strategies to reach these diverse groups. Programs should increase efforts to serve unmarried young women and recognize their needs and rights to sexual and reproductive health information and services. Moreover, health care providers in the public sector need to better understand and address the multiple disadvantages experienced by unmarried young women who approach them for sexual and reproductive health services. Counseling and the provision of services should be made available in a nonthreatening, nonjudgmental and confidential environment. Indeed, our findings highlight the need for the effective implementation of strategies outlined in the National Rural Health Mission's Reproductive and Child Health Programme. ${ }^{46}$ In addition, in-depth explorations of youth perspectives on ways to overcome barriers to care-seeking, and reasons underlying their preference for private-sector rather than public-sector providers, are critically needed. Further research is also necessary to assess providers' perspectives regarding the barriers they face in providing services to youth and possible ways to overcome these barriers.

\section{REFERENCES}

1. Ministry of Health and Family Welfare (MOHFW), National Population Policy 2000, New Delhi: Government of India, 2000.

2. MOHFW, National Health Policy, New Delhi: Government of India, 2002.

3. MOHFW, National Rural Health Mission: Meeting People's Health Needs in Rural Areas, Framework for Implementation, 2005-2012, New Delhi: Government of India, 2005.

4. National AIDS Control Organization (NACO) and MOHFW, National AIDS Control Programme, Phase III (2006-2011): Strategy and Implementation Plan, New Delhi: NACO, 2006.

5. Santhya KG, Reproductive tract and sexually transmitted infections, in: Jejeebhoy SJ, ed., Looking Back, Looking Forward: A Profile of Sexual and Reproductive Health in India, New Delhi: Rawat Publications, 2004, pp. 114-137.

6. Hawkes S and Santhya KG, Diverse realities: sexually transmitted infections and HIV in India, Sexually Transmitted Infections, 2002, 78(Suppl. 1):i31-i39.

7. International Institute for Population Sciences (IIPS), District Level Household and Facility Survey (DLHS-3), 2007-08: India, Mumbai: IIPS, 2010.

8. IIPS and Macro International, National Family Health Survey (NFHS-3), 2005-06: India, Vol. 1, Mumbai: IIPS, 2007.

9. Bhanderi MN and Kannan S, Untreated reproductive morbidities among ever married women of slums of Rajkot City, Gujarat: the role of class, distance, provider attitudes, and perceived quality of care, Journal of Urban Health, 2010, 87(2):254-263.

10. Sudha S, Morrison S and Zhu L, Violence against women, symptom reporting, and treatment for reproductive tract infections in Kerala state, southern India, Health Care for Women International, 2007, 28(3):268-284

11. Rani M and Bonu S, Rural Indian women's care-seeking behavior and choice of provider for gynecological symptoms, Studies in Family Planning, 2003, 34(3):173-185.

12. Prasad JH et al., Reproductive tract infections among young married women in Tamil Nadu, India, International Family Planning Perspectives, 2005, 31(2):73-82.

13. Patel $V$ et al., The burden and determinants of reproductive tract infections in India: a population based study of women in Goa, India, Sexually Transmitted Infections, 2006, 82(3):243-249.

14. Santhya KG, Jejeebhoy SJ and Ghosh S, Early Marriage and Sexual and Reproductive Health Risks: Experiences of Young Women and Men in Andhra Pradesh and Madhya Pradesh, India, New Delhi: Population Council, 2008.

15. Sadhu S et al., Reproductive morbidity among women in weaker sections in Calcutta metropolitan area, Demography India, 2001, 30(2):167-191.

16. Barua A and Kurz K, Reproductive health-seeking by married adolescent girls in Maharashtra, India, Reproductive Health Matters, 2001, 9(17):53-62.

17. Bhatia JC and Cleland J, Health-care seeking and expenditure by young Indian mothers in the public and private sectors, Health Policy and Planning, 2001, 16(1):55-61.

18. IIPS and ORC Macro, National Family Health Survey (NFHS-2), 1998-99: India, Mumbai: IIPS, 2000

19. Oomman N, Poverty and pathology: comparing rural Rajasthani women's ethnomedical models with biomedical models of reproductive morbidity, implications for women's health in India, unpublished dissertation, Baltimore: School of Hygiene and Public Health, Johns Hopkins University, 1996.

20. Ravindran TKS, Women's health situation in a rural poor population in Chengalpattu, Tamil Nadu, in: Das Gupta M, Chen LC and Krishnan TN, eds., Women's Health in India: Risk and Vulnerabilities, Mumbai: Oxford University Press, 1995, pp. 175-211.

21. Santhya KG and Jejeebhoy SJ, Sexual and reproductive health needs of married adolescent girls, Economic and Political Weekly, 2003, 37(41):4370-4380

22. Andrew G and Patel V, Health Needs of Adolescents: A Study of Health Needs of Adolescents in Higher Secondary Schools in Goa, AltoPorvorim, India: Resource Centre for Adolescent and Child Health, 2002.

23. Bang $\mathrm{R}$ and Bang B, Women's perception of white vaginal discharge: ethnographic data from rural Maharashtra, in: Gittelsohn $\mathrm{J}$ et al., eds., Listening to Women Talk About Their Health: Issues and Evidence from India, New Delhi: Har-Anand Publications, 1994, pp. 79-94.

24. Patel P, Illness beliefs and health-seeking behaviour of the Bhil women of Panchamahal district, Gujarat state, in: Gittelsohn J et al., eds., Listening to Women Talk About Their Health: Issues and Evidence 
from India, New Delhi: Har-Anand Publications, 1994, pp. 55-66.

25. Joshi BN et al., Reproductive health problems and help seeking behavior among adolescents in urban India, Indian Journal of Pediatrics, 2006, 73(6):509-513

26. Office of the Registrar General and Census Commissioner, Census of India 2000, age groups, 2001, <http://www.censusindia. gov.in/Census_Data_2001/Census_Data_Online/Social_and_ cultural/Age_Groups.aspx>, accessed Jan. 18, 2011

27. Ministry of Statistics and Programme Implementation, Gross state domestic product at current prices, 2009, <http://mospi.gov.in/ State-wise_SDP_1999-2000_20nov09.pdf>, accessed Feb. 21, 2011.

28. Office of the Registrar General and Census Commissioner, Census of India, Provisional Population Totals, Paper 2 of 2011, New Delhi: Office of the Registrar General and Census Commissioner, 2011.

29. IIPS and Population Council, Youth in India: Situation and Needs, 2006-07, Mumbai: IIPS, 2010.

30. Lan PT et al., Lack of knowledge about sexually transmitted infections among women in North rural Vietnam, BMC Infectious Diseases, 2009, Vol. 9, Art. 85, <http://www.ncbi.nlm.nih.gov/pmc/ articles/PMC2701953/>, accessed June 14, 2011.

31. Nguyen HN, Liamputtong $P$ and Murphy G, Knowledge of contraceptives and sexually transmitted diseases and contraceptive practices amongst young people in Ho Chi Minh City, Vietnam, Health Care for Women International, 2006, 27(5):399-417.

32. Lan PT et al., Perceptions and attitudes in relation to reproductive tract infections including sexually transmitted infections in rural Vietnam: a qualitative study, Health Policy, 2008, 86(2-3):308-317.

33. Santhya KG and Jejeebhoy SJ, Sexual and Reproductive Health of Young People in India: A Review of Policies, Laws and Programmes, New Delhi: Population Council, 2011.

34. Bhatia JC and Cleland J, Self-reported symptoms of gynecological morbidity and their treatment in south India, Studies in Family Planning, 1995, 26(4):203-216.

35. Jejeebhoy SJ, Santhya KG and Acharya R, Health and Social Consequences of Marital Violence: A Synthesis of Evidence from India, New Delhi: Population Council and United Nations Population Fund, 2010

36. Ackerson LK and Subramanian SV, Domestic violence and chronic malnutrition among women and children in India, American Journal of Epidemiology, 2008, 167(10):1188-1196.

37. Silverman JG et al., Intimate partner violence victimization prior to and during pregnancy among women residing in 26 U.S. states: associations with maternal and neonatal health, American Journal of Obstetrics \& Gynecology, 2006, 195(1):140-148.

38. Ahmed S, Koenig MA and Stephenson R, Effects of domestic violence on perinatal and early-childhood mortality: evidence from north India, American Journal of Public Health, 2006, 96(8):14231428.

39. Ramasubban R, Women's vulnerability: recent evidence on sexually transmitted infections, in: Ramasubban R and Jejeebhoy SJ, eds., Women's Reproductive Health in India, Jaipur, India: Rawat Publications, 2000, pp. 280-330

40. Santhya KG and Dasvarma GL, Spousal communication on reproductive illness among rural women in southern India, Culture, Health \& Sexuality, 2002, 4(2):223-236.

41. Jejeebhoy SJ and Koenig MA, The social context of gynecological morbidity: correlates, consequences and health seeking behaviour, in: Jejeebhoy SJ, Koenig MA and Elias C, eds., Reproductive Tract Infections and Other Gynecological Disorders: A Multidisciplinary Research Approach, Cambridge, UK: Cambridge University Press, 2003, pp. 30-81.

42. Mugaonkar VB et al., Perceptions of Bombay slum women regarding refusal to participate in a gynecological health program, in: Gittelsohn J et al., eds., Listening to Women Talk About Their Health: Issues and Evidence from India, New Delhi: Har-Anand Publications, 1994, pp. 145-167.

43. Joshi A, Dhapola M and Pelto PJ, Gynecological problems: perceptions and treatment-seeking behaviors of rural Gujarati women, in: Koenig MA et al., eds., Reproductive Health in India: New Evidence, New Delhi: Rawat Publications, 2008, pp. 133-158.

44. Bhatia JC and Cleland JC, Perceived gynecological morbidity, health-seeking behavior and expenditure in Karnataka, in: Koenig MA et al., eds., Reproductive Health in India: New Evidence, New Delhi: Rawat Publications, 2008, pp. 266-282.

45. Oomman N, A decade of research on reproductive tract infections and other gynecological morbidity in India: what we know and what we don't know, in: Ramasubban R and Jejeebhoy SJ, eds., Women's Reproductive Health in India, Jaipur, India: Rawat Publications, 2000, pp. 236-279

46. MOHFW, Implementation Guide on RCH II: Adolescent Reproductive Sexual Health Strategy, for State and District Programme Managers, New Delhi: MOHFW, 2006.

\section{RESUMEN}

Contexto: Entre las mujeres indias que reportan sintomas que sugieren infecciones del tracto reproductivo (ITR), una baja proporción busca tratamiento. La mayoría de los estudios sobre la búsqueda de tratamiento se han enfocado en todas las mujeres de edad reproductiva; poco se sabe acerca de dicha búsqueda en las mujeres adolescentes y jóvenes, especialmente las solteras.

Métodos: A partir de una encuesta representativa a nivel sub-nacional aplicada a jóvenes en la India en 2006-2008, se obtuvieron datos de 2,742 mujeres casadas y 2,108 solteras en edades de 15-24, quienes reportaron al menos un síntoma de ITR en los tres meses anteriores al estudio. Se condujo análisis de regresión logística multivariada para identificar asociaciones entre las características de las entrevistadas y la búsqueda de tratamiento de un proveedor médico formal. Además, entre las mujeres que recibieron atención médica, se identificaron las asociaciones entre sus características y el uso de proveedores privados en vez de públicos.

Resultados: Cerca de dos quintas partes de las jóvenes casadas con síntomas y una tercera parte de las solteras, habian buscado tratamiento de proveedores médicos. Mientras que haber sido víctima de la violencia intima de pareja se asoció negativamente con la búsqueda de tratamiento en las mujeres casadas (razón de momios, 0.8), el nivel de acceso percibido a los servicios de salud sexual y reproductiva y la conciencia de la mujer acerca de los síntomas estuvieron positivamente asociados con dicho tratamiento (1.3-1.4). Tanto las mujeres casadas como las solteras tuvieron mayor probabilidad de buscar tratamiento con proveedores privados en vez de públicos; $y$ dos indicadores de la autonomía de la mujer se correlacionaron positivamente con el uso de servicios privados (1.6-2.8).

Conclusiones: El bajo nivel de tratamiento de los sintomas de ITR en las mujeres jóvenes subraya la necesidad de abordar los desequilibrios de poder dentro del matrimonio y de alentar a los proveedores de servicios de salud a que desarrollen estrategias apropiadas para alcanzar las mujeres más jóvenes, así como las solteras. 


\section{RÉSUMÉ}

Contexte: En Inde, de faibles proportions de femmes déclarent chercher à faire soigner leurs symptômes évoquant une infection de l'appareil génital. La plupart des études relatives à la recherche de traitement sont largement concentrées sur les femmes en âge de procréer et on en sait peu sur l'expérience des adolescentes et des jeunes femmes, non mariées surtout.

Méthodes: Les données relatives à 2.742 femmes mariées et 2.108 femmes non mariées de 15 à 24 ans ayant déclaré avoir eu au moins un symptôme d'IAG durant les trois derniers mois écoulés ont été extraites d'une enquête sous-nationale concernant les jeunes menée en Inde en 2006-2008. Les associations entre les caractéristiques des répondantes et la recherche de traitement auprès d'un prestataire médical formel ont été identifiées par analyse de régression logistique multivariée. De plus, parmi les répondantes qui avaient eu recours à de tels prestataires, les associations entre les caractéristiques et le recours aux prestataires du secteur privé plutôt que public sont identifiées.

Résultats: Environ deux cinquièmes des femmes mariées et un tiers de celles non mariées s'étaient adressées à des prestataires médicaux formels pour le traitement de leurs symptômes d'IAG. Si l'expérience de la violence aux mains d'un partenaire intime est associée négativement à la recherche de soins auprès d'un prestataire formel parmi les femmes mariées $(\mathrm{OR}, 0,8)$, leur accès perçu aux services de santé sexuelle et génésique et leur conscience des symptômes des IST le sont positivement à ce traitement $(1,3-1,4)$. Les femmes mariées comme celles non mariées sont plus susceptibles de s'adresser aux prestataires du secteur privé et deux indicateurs d'autonomie des femmes présentent une corrélation positive avec le recours au secteur privé (1,6-2,8).

Conclusions: La recherche de traitement limitée des jeunes femmes en présence de symptômes d'IAG souligne le besoin de résolution du déséquilibre d'autorité au sein du mariage et d'encouragement des prestataires de soins de santé à élaborer des stratégies appropriées pour atteindre les femmes plus jeunes, de même que celles non mariées.

\section{Acknowledgments}

The Youth in India: Situation and Needs study was implemented by the International Institute for Population Sciences, Mumbai, and the Population Council, New Delhi. The authors gratefully acknowledge support for this study from The John D. and Catherine T. MacArthur Foundation and The David and Lucile Packard Foundation, and thank Shireen J. Jejeebhoy for her insightful comments on an early draft of this article.

Author contact: ssabarwal@popcouncil.org 